\title{
The nature and causes of chronic obstructive pulmonary disease: A historical perspective The Christie Lecture 2007, Chicago, USA
}

\author{
C Peter W Warren MA MB FRCPC
}

CPW Warren. The nature and causes of chronic obstructive pulmonary disease: A historical perspective. The Christie Lecture 2007, Chicago, USA. Can Respir J 2009;16(1):13-20.

Chronic obstructive pulmonary disease (COPD) is the currently favoured name for the diseases formerly known as emphysema and bronchitis. COPD has been recognized for more than 200 years. Its cardinal symptoms are cough, phlegm and dyspnea, and its pathology is characterized by enlarged airspaces and obstructed airways. In the 19th century, the diagnosis of COPD depended on its symptoms and signs of a hyperinflated chest, and reduced expiratory breath sounds. The airflow obstruction evident on spirometry was identified in that century, but did not enter into clinical practice. Bronchitis, and the mechanical forces required to overcome its obstruction, was believed to be responsible for emphysema, although the inflammation present was recognized. The causes of bronchitis, and hence emphysema, included atmospheric and domestic air pollution, as well as dusty occupations. Cigarette smoking only became recognized as the dominant cause in the 20th century. The lessons learned of the risks for COPD in 19th-century Britain are very pertinent to the world today.

Key Words: Bronchitis; COPD; Cotton; Emphysema; Pollution; Tobacco

\author{
Nature et causes de la bronchopneumopathie \\ obstructive chronique : Perspective historique. \\ Conférence Christie 2007, Chicago, É.-U.
}

La bronchopneumopathie obstructive chronique (BPOC) est le nom privilégié actuellement pour désigner les maladies que l'on nommait autrefois emphysème et bronchite. La BPOC est connue depuis plus de 200 ans. Ses symptômes cardinaux sont la toux, les expectorations et la dyspnée, et la maladie se caractérise par une dilatation des sacs alvéolaires et une obstruction des voies respiratoires. Au XIX ${ }^{\mathrm{e}}$ siècle, le diagnostic de $\mathrm{BPOC}$ se fondait sur ces symptômes, des signes de distension thoracique et la réduction des bruits respiratoires à l'expiration. L'obstruction respiratoire constatée à la spirométrie a été identifiée au cours de ce siècle sans pour autant être intégrée dans la pratique clinique. On considérait que la bronchite et les forces mécaniques requises pour surmonter l'obstruction respiratoire étaient responsables de l'emphysème, même si la composante inflammatoire était déjà reconnue. Les causes de la bronchite, et donc de l'emphysème, incluaient la pollution atmosphérique et domestique, de même que les poussières en milieu de travail. On n'a reconnu le rôle étiologique central du tabagisme dans la BPOC qu'au cours du $\mathrm{XX}^{\mathrm{e}}$ siècle. Les leçons que nous à enseignées l'Angleterre du XIX $\mathrm{X}^{\mathrm{e}}$ siècle relativement au risque de BPOC sont toujours d'actualité.

of those who do not wish to learn for themselves; those who ignore the past; and those who accept doctrines without critical examinations" (2). A historical perspective cannot include all articles on the subject; the number of articles is overwhelming. For instance, a PubMed search using the words "Anthonisen" - our first Christie lecturer - and "COPD" yields 74 articles. Aside from Rosenblatt's paper (2), Snider (3) has covered the history of emphysema and, moreover, justified the current use of the term COPD for the condition (4). In the present essay, a few key articles from the 19th and 20th century will be covered, in particular those that relate to the interests of Ronald Christie and his successor at McGill University, David Bates, who was our second Christie lecturer. The sources of information are from publications in medical libraries, mainly confined to English and French literature, and all those cited have been read in the original or in contemporary English language translations.

The inspiration for the present work came from an editorial on COPD published in Lancet by Suzanne Hurd and Claude Lenfant (5) with whom I have discussed my thesis. Two statements by them are "Although COPD is not a new disease, over the years many changes in its name, definition, of emphysema: "Medical history is replete with the mistakes

Correspondence: Dr Peter Warren, 5 River Lane, Winnipeg, Manitoba R2M 3Y8. Telephone 204-255-3281, e-mail warrencp@ms.umanitoba.ca 


\begin{tabular}{|c|c|c|}
\hline Year & Christie lecturer & Title of lecture \\
\hline 1988 & David Bates & RV Christie and lung disease \\
\hline 1992 & Margot Becklake & $\begin{array}{l}\text { Study of the epidemiology of airway } \\
\text { disease }\end{array}$ \\
\hline 1993 & William 'Whitey' Thurlbeck & Emphysema \\
\hline 1997 & James Hogg & $\begin{array}{l}\text { Windows on the new world: Latent viral } \\
\text { infections in the pathogenesis of } \\
\text { COPD }\end{array}$ \\
\hline 1999 & Joseph Milic-Emili & $\begin{array}{l}153 \text { years of blowing: Since John } \\
\text { Hutchinson }\end{array}$ \\
\hline 2000 & Clarence Guenter & "All the World's Our Stage" \\
\hline 2006 & Peter Paré & $\begin{array}{l}\text { The identification of susceptibility genes } \\
\text { for complex pulmonary and } \\
\text { cardiovascular disease }\end{array}$ \\
\hline
\end{tabular}

and diagnostic criteria have greatly thwarted our ability to make international comparisons of its prevalence", and "COPD is the only chronic disease for which the finger of blame can be pointed to a single risk factor - tobacco smoking". The present paper will confirm that COPD is not a new disease, although appearing under the guise of different names, that its diagnostic criteria have changed as technology developed, and finally that it was more common than generally recognized. The crux of the present paper, I will argue, is that if this lung disease was common before tobacco smoking in quantity was widespread, other risk factors must have contributed to its etiology.

\section{THE PATHOLOGY OF COPD}

Ruysch in the Netherlands (1691) published an illustrated catalogue of his museum of pathological specimens (6). For case number 20, he wrote "I discovered in a certain part of the lung a multitude of transparent vesicles, expanded with air and so obstructed that I was not able, with a light compression, to evacuate them of the air. I discovered by experiment that breath impelled through the trachea had no further connection with these expanded vesicles, on account of their obstruction. Later, when air was forcibly applied to the trachea, some of the vesicles were ruptured". The case was a merchant who died in 1685 who had "for a long time experienced difficulty breathing with persistent coughing and fever. The man was affected to such a degree that he committed suicide by drowning himself". Thus, Ruysch described it all - the obstruction, the hyperinflation, the dyspnea, the cough and the suicide - which is still a risk in the older patient (7).

The next important description is in Baillie's The Morbid Anatomy of Some of the Most Important Parts of the Human Body (8), which described and illustrated hyperinflated lungs with enlarged airspaces. There is good provenance that the lungs described are those of the celebrated Dr Samuel Johnson, essayist and lexicographer (9), who had a history of being "troubled for several years with asthma", in the sense of dyspnea, and developed dropsy - peripheral edema - which he died from. His autopsy was performed on
December 15, 1784, by James Wilson, who observed "on opening the cavity of the chest, the lungs did not collapse as they usually do when the air is admitted but remained distended, as if they had lost their power of contracting: the air cells on the surface of the trachea were somewhat inflamed". Hyperinflation, loss of elastic recoil and inflammation were thus suggested.

The modern era of COPD begins with Laënnec, who coined the term emphysema. Renowned for his invention of the stethoscope, it is often overlooked that his main research concerned the pathology of lung diseases. His seminal book, published in 1819, was his first book devoted to lung diseases. In 1821, John Forbes translated it (10). Laënnec preferred the name catarrh for the excessive mucus production from the mucous membranes of the airways, although in the fourth edition of his book he acknowledged that the term bronchitis was gaining favour for the condition. Laënnec divided catarrh into acute and chronic, with the former experienced by everyone, for he described the common cold. The symptoms of catarrh were cough and expectoration. He separated chronic catarrh into the humid and the dry - the former with copious expectoration, the latter with hardly any. Humid catarrh could have several natural histories - it may be mild with a good prognosis, but in some cases it may be attended by much dyspnea, often called asthma at that time. But this type of asthma was rarely paroxysmal and had a uniform intensity - ultimately, it could become suffocative. The dry catarrh he linked with emphysema, and its cough preceded the latter. The chapter ended with his beliefs that asthma may indeed be more than just a description for dyspnea, and that the spasmodic form may be a separate disorder.

Laënnec stated that emphysema was not very well known, and its key feature was that the vesicles were much enlarged in a random way. He fixed the lungs by inflating and air-drying them, and saw that the enlarged vesicles "were probably produced through rupture of the intermediate partitions; sometimes, however, they appear to arise from the simple enlargement of a single vesicle". Emphysema could be found in both lungs, one lung or parts of one lung. In the former, the lungs rose out of the chest when it was opened, and could not be easily deflated. Intriguingly, he observed at the inferior portion of the air cell cavities "small openings by which the dilated cells communicates with the adjoining ones, and with the bronchia". Were these the pores Kohn and Lambert described much later? Laënnec concluded that "the dry catarrh, and the obstruction of the bronchi, are the most common causes of emphysema" and found that "the smaller bronchial tubes are frequently completely obstructed" and might contain thick mucus; an observation confirmed by three Christie lecturers more than a century later (11).

Laënnec saw emphysema as the product of dry catarrh. The dilated air cells, often with destruction of their walls, indicated either a more "difficult communication between the air contained in the air cells and that in the bronchia, or else a diminished elasticity of the air cells themselves". A 
key passage in Laënnec's book is "Le catarrhe pulmonaire est l'inflammation de la membrane interne ou muqueux qui tapisse les bronches". Thus, Laënnec identified inflammation in COPD. For emphysema, the striking symptom was dyspnea worsened by exercise, emotion, indigestion and altitude. When severe, the skin was blue. Most interestingly, he stated that "the complaint often exists from childhood and does not seem to abridge the duration of life". Laënnec noted cardiac enlargement, noticeably of the right side of the heart.

The next major work regarding emphysema was by Louis (1837) in Researches on Emphysema of the Lungs, which was translated and published in Philadelphia (Pennsylvania, USA) one year later (12). "Emphysema", wrote Louis, "has been almost entirely neglected" since Laënnec, "nevertheless it is one of the most frequent and remarkable affections to be found in the whole catalogue of nosology". Louis collected data on 90 cases over two years, of whom 42 had died (23 from cholera). Louis described emphysema that could begin in infancy, but more frequently later in life. It was characterized by constant dyspnea that worsened with time, orthopnea, chronic catarrh punctuated by acute catarrh, and edema. At autopsy, the lungs did not collapse, the vesicles were dilated and the heart was hypertrophied. Louis saw that the vesicles had thickened cells in their walls, and attributed this to the law of economy; ie, membranous tissues become thicker when distended. This is the origin of the much used name over the next century - hypertrophic emphysema. The mean age of those who died 'naturally' of emphysema was 60 years, of those who died of cholera was 50 years, and of those still alive with emphysema was 40 years. He found the disorder usually appeared after an attack of acute catarrh. As well, Louis included the data of James Jackson, a postgraduate student in Paris (France) from Boston (Massachusetts, USA), who collected data on 41 cases in 10 months. Jackson made a strong case for heredity in the disease: 18 of his 29 patients with emphysema were offspring of parents who had the disease, while of 50 healthy people, only three had parents with emphysema; a precursor of Peter Paré's Christie lecture on susceptibility genes.

The first original English language book of A Treatise on the Diseases of the Chest was by William Stokes of Dublin, Ireland (13). He placed emphysema of the lung of Laënnec within the chapter on bronchitis. Stokes preferred to simply call emphysema dilation of the air cells, but recognized that rupture of the parities played a role. Stokes accepted the view that the obstruction of what he called the minute bronchi led to dilation and damage of the air cells. He suggested that the action of the circular fibres of smooth muscle would be important. In disease, these circular fibres increase in strength and irritability. Irritability, presumably now called hyperresponsiveness, fits with the Dutch hypothesis that asthma, in the modern sense, and COPD are related.

In 1840, Thomas Hodgkin, morbid anatomist at Guy's Hospital (London, United Kingdom), published his lectures to students (14). Hodgkin studied the terminations of the bronchial tubes and the cavities by which the inspired air is received. He made casts of the smallest airways by filling them with egg white and then boiling the lung to dissolve the tissues, leaving a cast of the coagulated albumin. Of emphysema, he stated: "It is an exceedingly common affection, and it is met with in every variety of extent and degree; and yet it does not appear that any other than extreme cases had attracted the attention of pathologists, until Laënnec gave a particular account, both of the morbid appearance, and of the symptoms that attend it". He agreed that emphysema of the lung was due to dilation of the air cells, which might at first sight be regarded as a form of hypertrophy, and that it had been described as such by a distinguished pathologist - presumably Louis. But most importantly, Hodgkin then said, "It may, however be much more correctly considered as an instance of atrophy; since the total weight of the lung is evidently reduced, and the vascularity of the texture, and the absolute extent of the surface exposed to the inspired air, are diminished". Unfortunately, he presents no hard data to support his observations.

\section{THE CLINICAL DIAGNOSIS OF COPD}

In the early 19th century, the clinical diagnosis of emphysema was based on the symptoms of dyspnea, the accompanying bronchitis by cough and expectoration, and on physical examination of the enlarged chest, the resonant percussion and the weak breath sounds. In his 1943 Goulstonian lecture, Christie reviewed the physical examination equated with the diagnosis of emphysema. In the history, $94 \%$ of patients had chronic cough and $78 \%$ had dyspnea on exertion. He found barrel chest to be most unreliable in the diagnosis of COPD. The best sign was prolonged expiration evident in $90 \%$ of patients (15). Long before Hoover, Stokes described the effects of the lowered diaphragm; "a remarkable difference from forced respiration in the healthy state for the corresponding ribs are drawn in" (16). Another sign of value that has been suggested is called Campbell's tug - the tracheal tug that occurs on inspiration due to the low diaphragm stretching the mediastinum. Of all signs, only the forced expiratory time, Christie's prolonged expiration, correlated best with the degree of obstruction (17).

\section{MEASUREMENT OF COPD}

Louis, in an essay on clinical instruction, wrote "To appreciate the value of symptoms, to know the progress and duration of diseases, to assign their degree of gravity, their relative frequency, the influence of constitutions upon their development, to enlighten ourselves as to the value of therapeutical agents, or the cause of disease it was indispensable to count" (18). The spirometer was to become the tool by which the progress, duration, gravity, cause and response to treatment in COPD could be counted. It came into clinical use with John Hutchison who first named and measured the vital capacity in 1846, and above all, obtained predictive values from measurements on 1200 men (19). His data showed that the vital capacity was related to height 


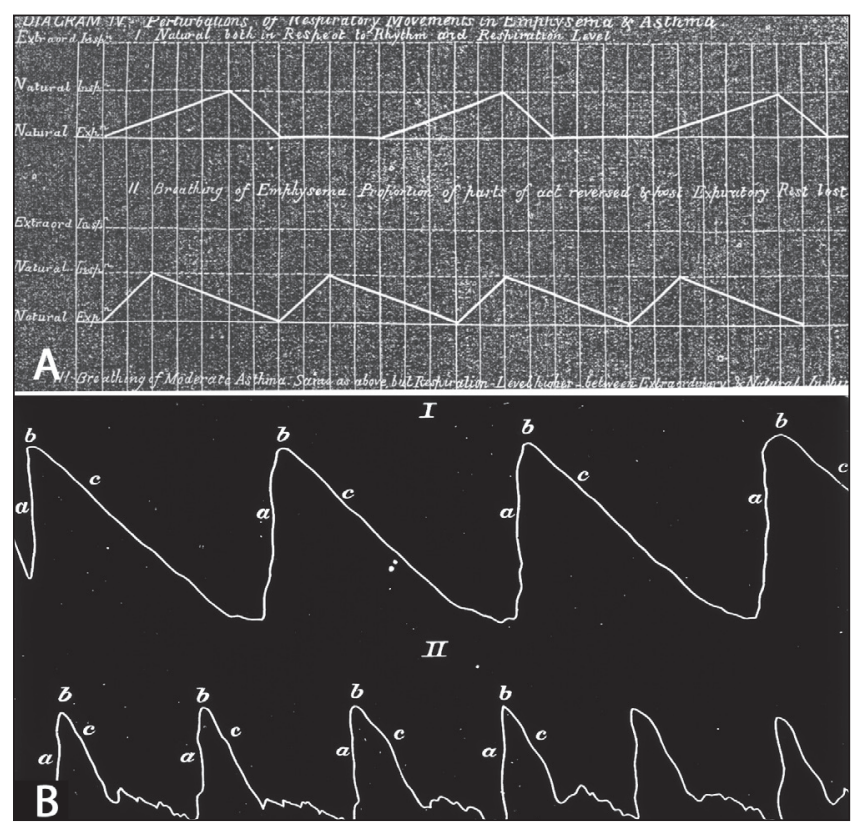

Figure 1) A Tidal spirograph of a person with normal respiration (above) or with emphysema (below). Adapted from reference 22. B Spirograph tracing of a person with normal respiration (I) or with emphysema (II). Adapted from reference 23

and to some extent age, but not to occupation. He concluded that the value of this technology was that it permitted "doctors, whether able or inept, to make accurate judgements. No exquisite sensory training was required to obtain or understand its data". He omitted any measurements on women because he found them unpredictable their corsets restricted the free movement of the chest and impeded the vital capacity. The first Canadian publication regarding the spirometer was in 1862 (20). That ethnicity should be added to Hutchinson's equations was demonstrated by a study of Union soldiers in 1869 (21).

But the key step for diagnosis of obstructive pulmonary disorders was the addition of the kymograph to the spirometer, thus providing volume time measurements. In 1866, Henry Hyde Salter, best known for his book on asthma, used the spirometer to study dyspnea (22). Salter stressed the objectivity of using his technology and with his tracings wrote, physicians "view seeing as believing.... They will have the same kind of value as a photograph.... The lines will not be 'doctored' whatever the patient may be. There will be no disputing them; it will be impossible to say that they are the result of imagination or error". His paper included idealized graphs of normal respiration and the lower volume and prolonged expiration of a person with emphysema (Figure 1A). Actual tracings by Landois (Figure 1B) confirmed that prolonged and reduced expiration, and indeed scooping, is found in emphysema (23). Christie included a similar spirographic tracing from a case of advanced emphysema in his first paper (24). In the second half of the 20th century, the examination of volume-time relationships in tidal respiration switched to the unnatural forced expiratory test - the French credit Tiffeneau with this manoeuvre in 1947, but
Anglophones ignore the French literature and credit Ed Gaensler (25). Fifty years ago, Bryan Gandevia recommended the term $\mathrm{FEV}^{\mathrm{n}}$ to the British Thoracic Society (26), and this reliable workhorse has become the sine qua non that we use to diagnose COPD - our CTS guidelines state the forced expiratory volume in $1 \mathrm{~s} /$ forced vital capacity ratio to be the most important measurement.

\section{THE PREVALENCE OF COPD}

The overwhelming evidence is that COPD was common. Laënnec wrote, "I had long time thought it very uncommon...am led to consider it as by no means infrequent". Louis described it as "one of the most frequent and remarkable affections to be found" (12), and had gathered one of the first epidemiological studies of the disease - the subject of Margot Becklake's Christie lecture. Louis found evidence of emphysema in $50 \%$ of the cases that died from cholera and that it was most frequently located in the upper lobes. Again, a century later, Thurlbeck (27) found emphysema in $49.3 \%$ of random autopsies in Boston and the centrilobular form favoured the upper lobes. In a very large series, Samuel Gee (28) found emphysema in $11.3 \%$ of 1363 consecutive autopsies at St Bartholomew's Hospital (London, United Kingdom) from 1894 to 1897 . Such remarks as the recent Wouters' title of COPD as an overlooked disease (29) is reminiscent of Laënnec and Louis, while the Burden of Lung Disease (BOLD) study (30), which reported a COPD prevalence of $11.8 \%$ (a rate higher than typically reported), simply ignores Gee's century-old findings. On the other hand, Gee cites the great pathologist Virchow as reporting emphysema in only $0.3 \%$ of nearly 200,000 cases admitted to the Charite Hospital, Berlin, Germany. As Thurlbeck has noted, very clear comparisons in pathology are dependent on methods of preparing the lungs, let alone the method of observing them, and the same applies to studies in the living.

\section{THE PATHOGENESIS OF COPD}

Laënnec reasoned that the obstruction of the small bronchi produced damaging forces on the alveolar walls, either on inspiration, as pressure was exerted to suck the air in, or on expiration, when pressure was needed to force air out. This hypothesis was accepted by all 19th-century writers, although whether the dominant force to overcome the obstructed bronchi was on expiration or inspiration was much debated. Certainly Christie (15) examined the pathogenesis of emphysema and dismissed the theory that coughing produced hyperinflation, and thus loss of elasticity - the phenomenon we observe in a chronically stretched elastic band. $\mathrm{He}$ argued that the force of coughing (with as much as $50 \mathrm{mmHg}$ of pressure exerted on the alveoli), before the glottis opens, sends a pressure wave through the lung and stresses the alveolar walls, (which are not robust) consequently causing degenerative changes. Other theories included that emphysema was a congenital disorder, that it was secondary to an expanded chest wall or that it was due to malnutrition of the alveoli, partly the result of increased 
alveolar pressure impeding the blood supply. Laënnec had suggested that emphysema was more common in wind instrument players. This suggestion remained in the medical literature until finally dismissed by Ronald Christie, who found no supporting evidence (31). All theories were put in abeyance, by what John Murray called the serendipitous finding in the Swedish population by Eriksen, that emphysema was associated with alpha-1 antitrypsin deficiency (32). This has meant that inflammation as a cause of the disease is now most favoured. Laënnec's observation of inflammation in what he called the capillary bronchi is vindicated. Nonetheless, mechanical destruction does play a role, for West proposed that mechanical forces are responsible for the finding of centrilobular emphysema in the upper lobes (33), and the Biomedical Engineering group at Boston University (Boston, Massachusetts) believes mechanical forces do add to the inflammatory damage in emphysema (34).

\section{THE CAUSES OF COPD}

Laënnec, Louis, Stokes and Hodgkin accepted that emphysema was a complication of catarrh, bronchitis. Thus, the causes of bronchitis, identified by such authors, can be used as surrogates for the causes of both emphysema and COPD. Bradford Hill's criteria of causation must be kept in mind (35). Laënnec linked catarrh with gouty and hypochondriacal people, with people whose bodies were broken down by excesses of any kind, and with people who lived by the sea coast or in damp valleys. He also observed catarrh in people who had been exposed to the gas of cesspools, and in a footnote, speculated that $\mathrm{CO}_{2}$ with its higher specific gravity might be damaging to the lungs. In 1866, Copland stated that the major cause of chronic bronchitis was the inhalation of the molecules or particles of mineral, vegetable and animal substances (36). No mention of tobacco smoke was made.

Tobacco has been used in different forms over the centuries, first as pipe tobacco, then as snuff, then the cigar, with the cigarette introduced in Europe with the Crimean War and in North America with the Civil War (37). It is likely that tobacco consumption, although common, was at a low level until cigarette mass production began circa 1880 (38). The accessibility, marketing and increased nicotine content of cigarettes resulted in a huge increase in tobacco sales. For instance, in Britain, cigarettes resulted in tobacco consumption levels that soared above population growth up to the present (Figure 2).

We do not know the smoking habit of the cases described by Laënnec, Louis and Stokes. Only Hodgkin, who wrote a pamphlet condemning smoking, associated tobacco use with disorders of the mucous membranes, but not specifically bronchitis (39). For Baillie's case (Samuel Johnson), we do have information. Boswell wrote of Johnson, "Smoaking [sic] of the sedative influence of which he himself never smoaked, he had a high opinion" (40). While the historian Conte Corti quoted Johnson as stating, "To be sure it is a shocking thing, blowing smoke out of our mouths into other people's mouths, eyes, and noses and having the same thing

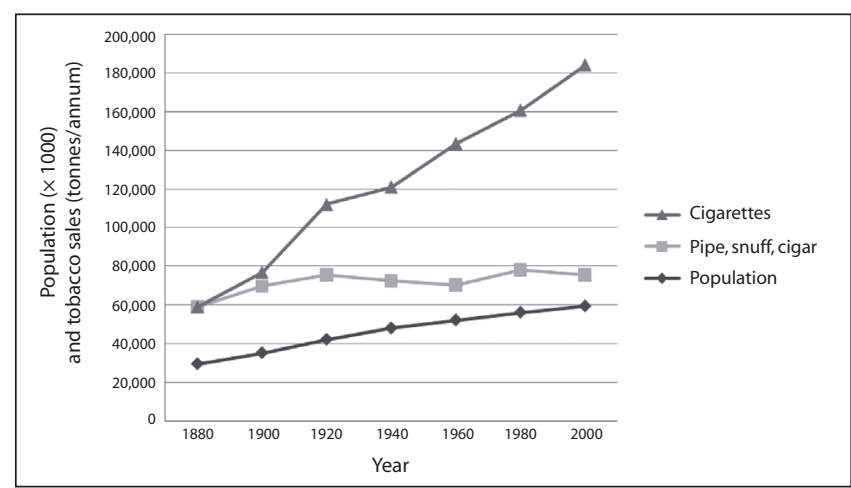

Figure 2) Population growth and tobacco sales for cigarettes and other forms (pipe, cigar, snuff) in the United Kingdom from 1880 to 2000. Data adapted from reference 38

done to us" (37). Was Johnson's emphysema from secondhand smoke?

Having accepted that in the 19th century, emphysema and bronchitis usually co-existed, it is possible to use the diagnosis of chronic bronchitis in epidemiological studies to examine their possible causes. Even 50 years ago, leading English and American textbooks had only just begun to acknowledge that excessive smoking was a factor in chronic bronchitis. The overwhelming evidence of the catastrophic effects of tobacco smoking on the lungs - first for cancer then COPD - was only established once the latent effects of cigarettes became apparent in the second half of the 20 th century. So, if we accept that tobacco was smoked in small amounts in the 19th century, what other factors might have caused COPD? Ogilvie (41) showed in 1961 that the mortality for bronchitis in England and Wales (United Kingdom) far exceeded that in other countries irrespective of tobacco consumption, particularly in urban communities. The distribution of bronchitis mortality in England and Wales revealed that the highest rates lay in industrial cities, with Manchester (United Kingdom) having the worst rate (42). Although not ruled out, it seems unlikely that Mancunians smoked tobacco to a greater extent than the rest of Britain.

\section{ATMOSPHERIC POLLUTION}

Did this urban predominance apply to the 19th century? Yes! Ransome, a leading lung and tuberculosis specialist in Manchester, reported a mortality rate in that city that was three times the rate in the rural Lake District (United Kingdom), with respiratory deaths being the major cause, and double that of tuberculosis (43). Manchester at that time was the leading industrial city of the world; its economy based on cotton and linen mills powered by coal burning steam plants - The Chimney of the World as Mosley entitled his book on the subject (44). The mills and domestic fires produced a constant pall over its skies. This belief in the importance of urban pollution, and in particular coal smoke, as a cause of lung disease had been expressed by Charles Dickens, in the opening paragraph of the second 
volume of Our Mutual Friend, 1865, "Animate London with smarting eyes and irritated lungs was blinking, wheezing and choking; inanimate London was a sooty spectre" (45). This conclusion was shared by medical experts. In 1868, Manchester's first Medical Officer of Health, Dr Leigh, made air pollution his target and said, "The normal condition of the working man of middle age in Manchester is bronchitic" and he continued, "the solid particles constantly floating in the atmosphere from our factory chimneys, and other sources, keep up a constant irritation in the air tubes, producing ultimately chronic bronchitis and emphysema of the lungs" (46).

\section{DOMESTIC POLLUTION}

Atmospheric pollution was believed to be unhealthy, but what about inside the house? Friedrich Engels wrote on the conditions of the overcrowded Manchester slums in which the poor huddled (47). He blamed the poor ventilation in the houses for their mortality. His results conclude that "the harmful influence of an abnormal atmosphere" to which the families were exposed was a lack of oxygen, an excess of $\mathrm{CO}_{2}$ and the putrefying material that accumulated due to the lack of sewage and garbage disposal. Ransome (43) also examined the risk of foul air on health. His first concern was trades and manufacturers' dusts that "caused inflammation or other damage to the lungs". He was well aware of the huge problem of putrefaction as a source of miasma, but he believed it was "hard to confirm a relation to lung diseases". Ransome blamed high $\mathrm{CO}_{2}$ levels in ill-ventilated houses as the paramount villain for ill health (43). Mosley has researched the role of the open fireplace on ventilating the British home (48). The passage of heated air up the chimney ensured that, what I will euphemistically call fresh air, was sucked in through open windows and doors, so ensuring a more salubrious breathing atmosphere. Thus, if one was not exposed to smoke from a back draft from the fireplace, this ensured that the surrounding external smoke was brought into the house. The key was that it flushed out the $\mathrm{CO}_{2}$ and any putrefactive material. As the germ theory replaced that of miasma as the cause of disease, some even argued that the smoke might act as a natural antiseptic.

\section{OCCUPATION}

Ransome had listed trade and manufacturer's dust as a cause of lung disease. Engels (47) also described the deleterious effects of the dust: "But besides all this, there are some branches of factory work which may have an especially injurious effect. In many rooms of the cotton and flaxspinning mills, the air is filled with fibrous dusts, which produces chest affections, especially among workers in the carding and combing- rooms" (47). Thackrah (49), in 1832, studied workers in the linen industry and found much evidence of lung disease. Interestingly, he supplemented his physical examination of the workers with a measurement of their lung function with what he called the pulmometer - a jar inverted and filled with water into which the subject blew a full expiration. He implied that the workers had lower capacities than expected, but he had no firm predicted values for comparison. He did not think that cotton weavers were unhealthy - this may reflect that he only visited one mill and he found it to be well ventilated, with scarcely any dust.

In the mid-19th century, two novelists described the appalling conditions of work in the cotton mills. Francis Trollope used the plight of these children in her novel The Life and Adventures of Michael Armstrong, the Factory Boy (50). At this time, more than 200,000 children as young as five years of age and working 15-hour days were employed in the mills. Another novelist Elizabeth Gaskell, in North and South (51), told how when cotton was carded, the fine white dust wound round the lungs and "tightens them up". Although Victorian legislation increased the age and improved the hours of child workers, the dust exposure was not controlled until the 1930s, when cotton dust was recognized as a cause of the lung disease known as byssinosis. This form of bronchitis with irreversible obstruction was worsened by the surrounding air pollution (52). That other organic dusts can cause emphysema is suggested by the finding of increased compliance in patients with chronic hypersensitivity pneumonitis (53), a disease apparently more common among nonsmokers (54).

\section{CONTROLLING POLLUTION}

The lessons of the frequency and associations, probably causal, of COPD under the diagnostic label of bronchitis in the 19th century show that air pollution, inside and outside the home, and at work, played a part. Even if the specific cause of the problem within the house - excess $\mathrm{CO}_{2}$ and miasma from putrefaction - were wrongly blamed, both represented the overcrowding that, presumably, encouraged the spread of respiratory infections. Although outdoor pollution as a cause of disease may have been downplayed, Ransome saw that improving air quality would be difficult and not be voluntary. He wrote, "Purity of out-door air can only be attained by legislation and good local government" but realized that it would entail "interfering with the prosperity of trade and commerce, though where human life and health are concerned I think some interference would be justified" (43). A century later, David Bates found the same difficulties of decision making in a free society. The legislation has to balance what the public wants, an unfettered economy and use of energy, against the risks it ignores from the consumption of the fuel necessary (55).

In the late 19th century, industrial smoke production was regulated to some extent, but industrialists generally avoided prosecution for nuisance by building taller chimneys. But onehalf of the pollution was from home fires, and although the contribution of domestic smoke was recognized, it was a lost cause to regulate it (56) because the British domestic fire was sacred to home life - as expressed in Ivor Novello's patriotic song of World War I "Keep the home fires burning". Nothing was done about this until December 1952, when, due to a temperature inversion, a London smog produced a record rise in smoke and sulphur dioxide levels, accompanied by a significant rise in daily deaths - approximately 4000 excess deaths in three days and another 8000 over the next months (57). Experience as a physician during this disaster inspired David Bates's 
lifelong crusade against pollution. Legislation was finally passed to control smoke because of its health hazard, and the domestic coal fire in Britain became a thing of the past.

\section{TODAY'S WORLD}

In his Christie lecture, Guenter drew our attention to "All the World's Our Stage". Pollution has changed, for it is the automobile that produces a less visible and subtler form of pollution than coal. In developing economies, for instance China, a coal-fired industrial economy, gasoline fuelled transport (58) and cigarettes introduced by Western capitalism pose a potential respiratory disaster (59). Occupational hazards are still with us. As Khan and Nanchal (60) recently warned, "With rapid industrialization of the developing world, cotton induced lung diseases are poised to become a global health problem".

In Canada, the overcrowding and lack of ventilation in the homes of our First Nations people contribute to the spread of infections that damage the lungs of children (61), and predisposes them to COPD (62); infection being a factor referred to by James Hogg in his Christie lecture. At least North Americans are spared domestic smoke pollution because of the enclosed stove, invented by Benjamin Franklin as an energyconserving device, which is favoured in North America. But in the rest of the world, the World Health Organization shows a high rate of deaths from indoor smoke from solid fuels, admittedly wood and dung rather than coal, and used mainly for cooking, not heating (63). Studies (64) have demonstrated that indoor smoke is just as harmful as cigarette smoking for COPD.

\section{CONCLUSION}

COPD, under its former names of bronchitis and emphysema, is not a new disease and has always been ignored. It existed before heavy tobacco smoking, particularly in the form of the cigarette, was widespread. The lessons of the 19th century are that overcrowded homes, and atmospheric, domestic and occupational pollution contribute to its development. Whether these factors make an individual vulnerable to the added insult of the cigarette, or produce the disease in their own right can be debated. Certainly Mannino and Buist (65) have accepted that there is no single risk factor for COPD.

ACKNOWLEDGEMENTS: The author thanks the staff of the Neil John MacLean Library, University of Manitoba, the Osler Library, McGill University, the Wellcome Library and the British Library. The author also thanks Paul Potter, University of Western Ontario and James Chlup, University of Manitoba for Latin translations.

\section{REFERENCES}

1. Christie RV. Galen on Erasistratus. Perspect Biol Med 1987;30:440-9.

2. Rosenblatt MB. Emphysema in the nineteenth century. Bull Hist Med 1969;43:533-52.

3. Snider GL. Emphysema: The first two centuries - and beyond: A historical overview with suggestions for future research: Part 2. Am Rev Respir Dis 1992;146:1615-22.

4. Snider GL. Nosology for our day. Its application to chronic obstructive pulmonary disease. Am J Respir Crit Care Med 2003;167:678-83.

5. Hurd S, Lenfant C. COPD: Good lung health is the key. Lancet 2005;366:1832-3.

6. Ruysch F. Observationes anatomico-chirurgicae. Amsterdam 1671;1.

7. Fierson RL. Suicide attempts by the old and very old. Arch Int Med 1991;151:141-4.

8. Baillie M. The Morbid Anatomy of Some of the Most Important Parts of the Human Body. London: W Bulmer, 1803.

9. McHenry LC. Dr. Samuel Johnson's emphysema. Arch Int Med 1967;119:98-105.

10. Laënnec RTH. A Treatise on the Diseases of the Chest, in Which They are Described According to Their Anatomical Characters and Their Diagnosis Established on a New Principle by Means of Acoustic Instruments. London: T \& G Underwood, 1821. (Translated into English by John Forbes; Treatise was originally published in France, in 1818).

11. Hogg JC, Macklem PT, Thurlbeck WM. Site and nature of airway obstruction in chronic obstructive lung disease. New Engl J Med 1968;278:1355-60.

12. Louis PCA. Researches on Emphysema of the Lungs. Stewardson T Jr, trans. Philadelphia: Dunglingtons American Medical Library. 1838:491-552.

13. Stokes William. A Treatise on the Diagnosis and Treatment of Diseases of the Chest, 1837. London: The New Sydenham Society, 1882.

14. Hodgkin T. Lectures on Pathologic Anatomy. London: Simpkin, Marshall and Co, 1840;2.

15. Christie RV. Emphysema of the Lungs. BMJ 1944;105:143-6.

16. Stokes W. Researches on Laennec's vesicular emphysema, with observations on paralysis of the intercostal muscles and diaphragm, considered as a new source of diagnosis. Dublin J Med Sci $1836 ; 27-59$

17. Campbell EJM. Physical signs of diffuse airways obstruction and lung distention. Thorax 1969;24:1-3.

18. Louis PCA. An Essay on Clinical Instruction. Martin P, translator. London: S. Highley, 1834.

19. Hutchison J. On the capacity of the lungs, and on the respiratory functions. Medico-chirurgical transactions 1846;29:137-252.

20. Bowman WE. A cheap spirometer. Canada Lancet 1862;1:27-8.

21. Braun L. Spirometry, measurement, and race in the nineteenth century. J Hist Med 2005;60:135-69.

22. Salter HH. Lectures on dyspnea. Lancet 1866;84:153-62.

23. West S. Diseases of the organs of respiration. Quoting Landois L. A Text-book of Human Physiology. Translated by Stirling W. 1885. London: Charles Griffin and Company Ltd, 1909.

24. Christie RV. The lung volume and its subdivisions: I. Methods of measurement. J Clin Invest 1932;11:1099-118.

25. Yernault JC. The birth of the forced expiratory manoeuvre: A tribute to Robert Tiffeneau (1910-1961). Eur Respir J 1997;10:2704-10.

26. Gandevia B, Hugh-Jones P. Terminology for measurements of ventilatory capacity. 1957;12:290-3.

27. Thurlbeck WR. The incidence of pulmonary emphysema, with observations on the relative incidence and spatial distribution of various types of emphysema. Am Rev Respir Dis 1963;87:206-15.

28. Gee S. The Lumleian lectures on bronchitis, pulmonary emphysema, and asthma. Brit Med J 1899;645:715-24.

29. Wouters EFM. COPD: A chronic and overlooked pulmonary disease. Lancet 2007;370:715-6.

30. Buist AS, McBurney MA, Vollner WM, et al. International variation in the prevalence of COPD (the BOLD study): A population-based prevalence study. Lancet 2007;370:741-50.

31. Christie RV. Chronic hypertrophic emphysema: The aetiology and the cause of some of its signs and symptoms. Edinburgh postgraduate lectures in medicine 1938;1:288-98.

32. Murray JF. Voltaire, Walpole amd Pasteur: Variations on the theme of discovery. Am J Respir Crit Care Med 2005;172:423-6.

33. West JB. Distribution of mechanical stress in the lung, a possible factor in localisation of pulmonary disease. Lancet 1971;1:839-41.

34. Suki B, Lutchen KR, Ingenito EP. On the progressive nature of emphysema. Roles of proteases, inflammation and mechanical forces. Am J Respir Crit Care Med 2005;168:516-21.

35. Hill AB. The environment and disease: Association or causation. Proc Roy Soc Med 1965;58:295-30.

36. James Copland. The Forms, Complications, Causes, Prevention and Treatment of Consumption and Bronchitis Comprising also the 
Causes and Prevention of Scrofula. London: Longmans, Green and Co, 1866.

37. Corti C. A History of Smoking. Paul England, translator. London: London Bracken Books, 1931.

38. Forey B, Hamling J, Lee P, Wald N. International Smoking Statisitics. A Collection of Historical Data from 30 Economically Developed Countries, 2nd edn. Oxford: Oxford University Press, 2002.

39. Hodgkin T. On the Physical, Moral and Social Effects of Tobacco. Bradford: William Byles \& Sons, 1859.

40. Boswell J. The Life of Samuel Johnson, 1791. London: Oxford University Press, 1953.

41. Ogilvie AG. Frequency of bronchitis in Europe and the U.S.A. In: Orie NGM, Sluiter HJ, eds. Bronchitis: An International Symposium. Netherlands: Charles C Thomas, 1961.

42. Reid DD. General epidemiology of chronic bronchitis. Proc Roy Soc Med 1976;49:767-71.

43. Ransome A. On foul air and lung disease. The Sanitary Review 1872;6:6-13.

44. Mosley S. The Chimney of the World. A History of Smoke Pollution in Victorian and Edwardian Manchester. Cambridge: The White Horse Press, 2001.

45. Dickens C. Our Mutual Friend, 1865. London: Collins, 1937;2.

46. Shock Cities: The Environmental Transformation and Reform of Manchester and Chicago. Chicago: The University of Chicago Press, 2005.

47. Engels F. The Condition of the Working Class in England, 1845. London: Penguin Classics, 2005.

48. Mosley S. Fresh air and foul: The role of the open fireplace in ventilating the British home, 1837-1910. Planning Perspectives 2003;18:1-21.

49. Thackrah CT. The Effects of Arts, Trades, and Professions and Habits of Living on Health and Longevity. London: Longman, 1832.
50. Trollope F. The Life and Adventures of Michael Armstrong, the Factory Boy. London: Henry Colburn, 1840.

51. Gaskell E. North and South, 1854. London: Oxford University Press, 1973.

52. Byssinosis and atmospheric pollution. Lancet 1964;2:299-300.

53. Warren CPW, Tse KS, Cherniack RM. Mechanical properties of the lung in extrinsic allergic alveolitis. Thorax 1978;33:315-21.

54. Warren CPW. Extrinsic allergic alveolitis: A disease commoner in non-smokers. Thorax 1977;32:567-9.

55. David Bates. Environmental Health Risks and Public Policy. Decision Making in a Free Society. Vancouver: UBC Press, 1994.

56. Brimblecombe P. The Big Smoke. A History of Air Pollution in London Since Medieval Times. London: Routledge, 1987.

57. Beaver H. Committee on Air Pollution. Interim Report. Cmd 9011, 1953.

58. Watts J. China: The air pollution capital of the world. Lancet 2005;366:1761-2.

59. Lee K, Collin J. "Key to the future": British American tobacco and cigarette smuggling in China. PLOS medicine 2006;3;e228.

60. Khan AJ, Nanchal R. Cotton dust lung diseases. Curr Opin Med 2007; 13:137-41.

61. Kovesi T, Gilbert NI, Stocco C, et al. Indoor air quality and the risk of lower respiratory tract infections in young Canadian Inuit children. CMAJ 2007;177:155-60.

62. Silverman M, Kuehni CE. Early lung development and COPD. Lancet 2007;370:717-9.

63. World Health Organization. Indoor air pollution. <http://www.who. int/indoorair/en/> (Version current at December 23, 2008).

64. Ramírez-Venegas A, Sansores RH, Pérez-Padilla R, et al. Survival of patients with chronic obstructive pulmonary disease due to biomass smoke and tobacco. Am J Respir Crit Care Med 2006;173:393-7.

65. Mannino DM, Buist AS. Global burden of COPD: Risk factors, prevalence and future trends. Lancet 2007;370:765-73. 


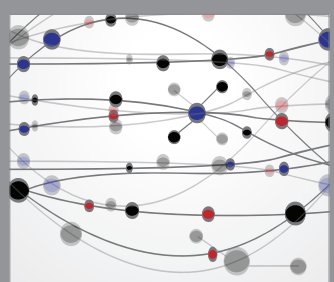

The Scientific World Journal
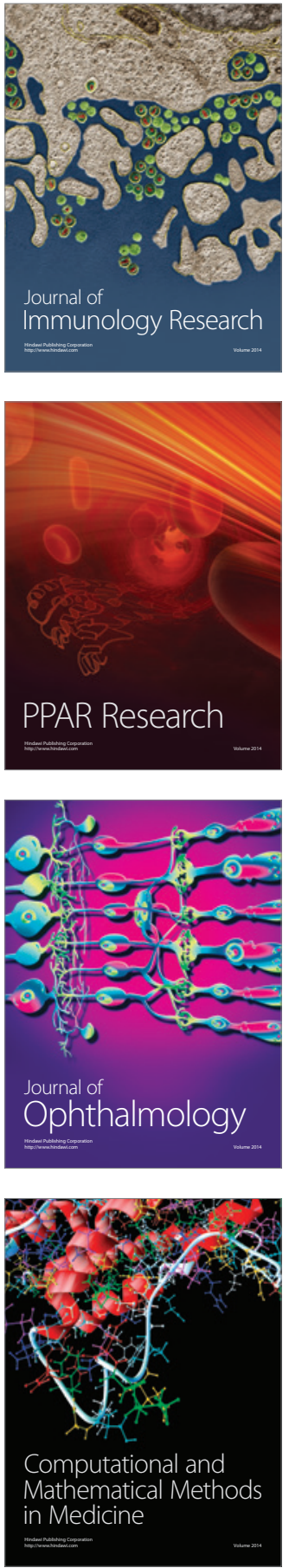

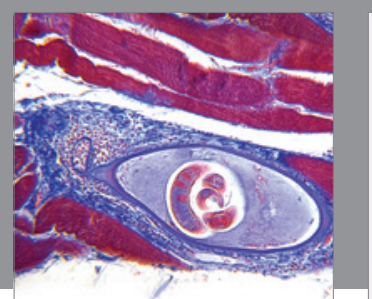

Gastroenterology Research and Practice

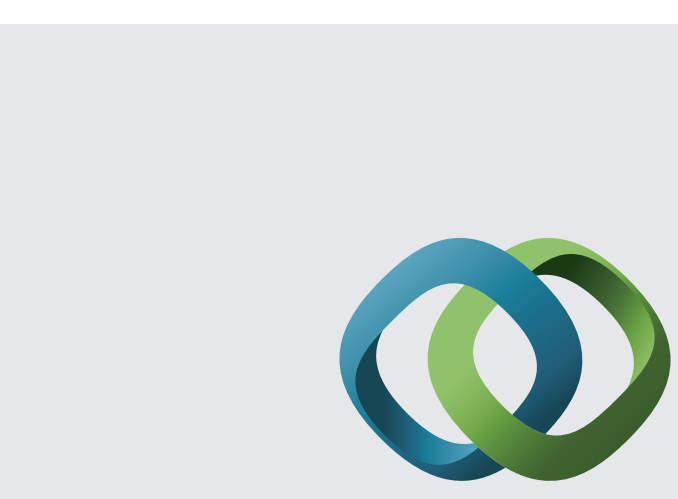

\section{Hindawi}

Submit your manuscripts at

http://www.hindawi.com
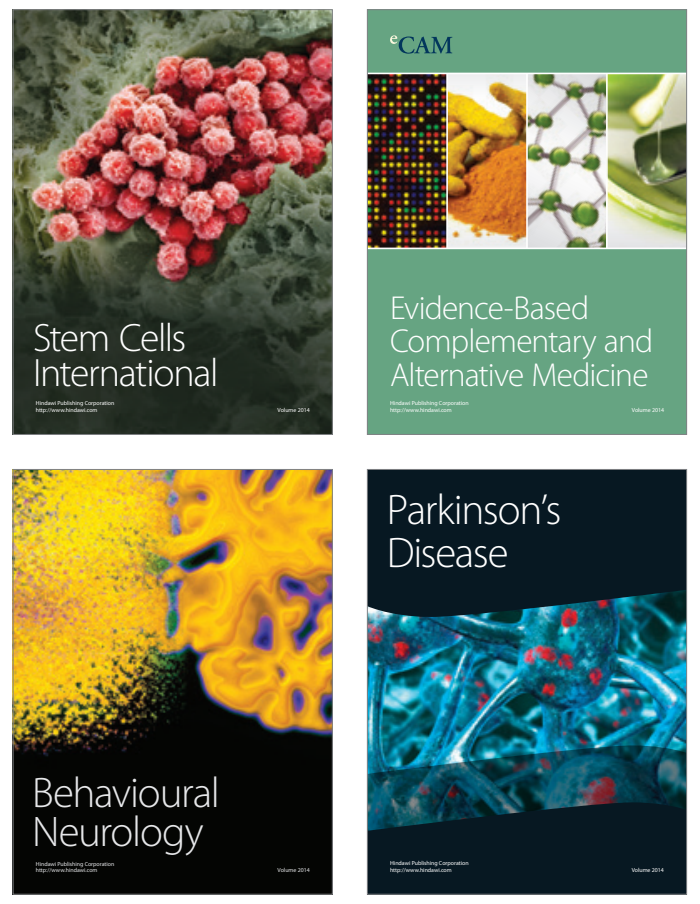
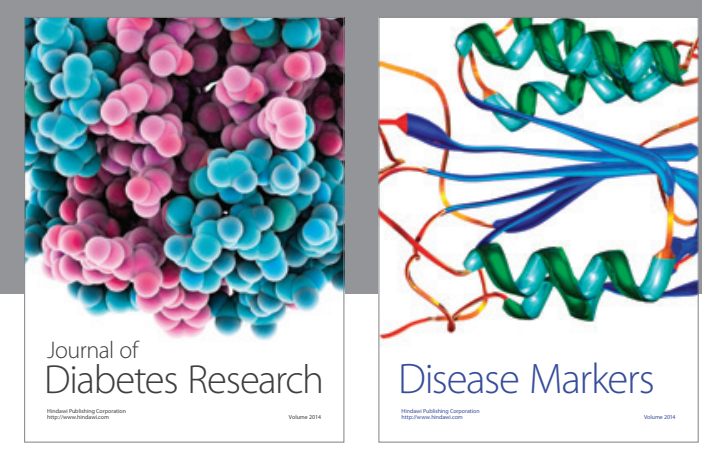

Disease Markers
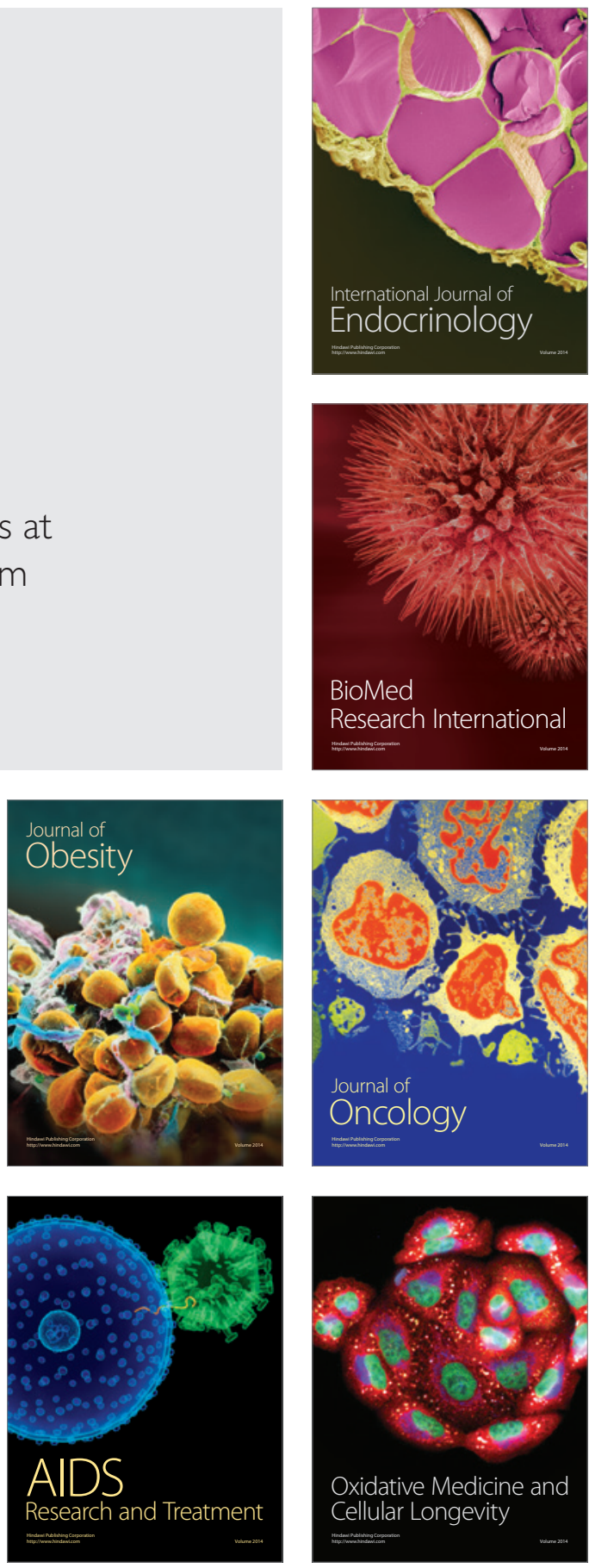